\title{
Effectiveness of School Administrators' Leadership Skills and Behaviors and their School Performance in Area III Leyte Division, Philippines
}

\author{
Vilma S. Pricellas ${ }^{1 *}$, Roland A. Niez $^{2}$, Reggie N. Nierra ${ }^{3}$, Allan Paul U. Tubis ${ }^{4}$ \\ ${ }^{l}$ Caruyucan Elementary School, Calubian North District,Division of Leyte \\ ${ }^{2,3}$ Naval State University, Naval, Biliran 6560 Philippines \\ ${ }^{4}$ Department of Education, Biliran Division
}

\begin{abstract}
This study aimed to determine the leadership skills and behaviors of school administrators and their school performance in Area III Leyte Division. It employed the descriptive-correlational research method as the main technique of the study. As to the profile of school administrators, majority were old-age, more than half were female, nearly eighty percent were married, a bigger number were master's degree holders, a little more than one-half occupied Principal 1 position, mostly availed only local and regional trainings/seminars and a great majority of them had served more than 9 years. Looking on the aspect of leadership skills, the school administrators were highly effective in all areas such as setting instructional direction, teamwork, sensitivity, judgment, results orientation, oral communication, written communication, developing others, understanding own strengths and weaknesses. In terms of leadership behavior, the school administrators were also found to be highly effective in all areas such as in communicating the school goals, supervision and evaluation of instruction, coordinating the curriculum, monitoring of student progress, protecting instructional time, maintaining high visibility, providing incentives for teachers, promoting professional development and providing incentives for learning.Parallel studies maybe conducted by examining other aspects and nature of variables related to leadership skills and behavior so that further assessments on the reliability and validity of the data in this research could be ascertained.
\end{abstract}

Keywords: School administrator, leadership skills, leadership behavior, school performance

\section{Introduction}

The actions of school leaders impact school capacity and may either enhance or diminish student achievement. School capacity is defined as the collective power of a school staff to raise student achievement (King \&Youngs, 2002). The effective educational leader is one who has the ability to develop a school's capacity to enhance student learning through the motivation of teachers, staff and students (Daley, Guarino\&Santibanez, 2006). Such leadership is determined by the followers, not the leaders (Bhindi, Hansen, Rall, Riley, \& Smith, 2008).

School administrators who build school capacity through an effective leadership style may influence student achievement through teachers (Christie, Thompson, \&Whiteley, 2009). The school leader must have or be able to develop the capacity to work with staff to focus on curriculum, instruction and student learning gains (Fullen, 2001). The perception of the school administrator is often as a person who manages a school and not as a person who is an instructional leader. The leader's daily activities and decisions reflect the pervasive focus and style of the school's leadership (Noonan \& Walker, 2008). A teacher-focused leader works toward the development of school capacity which builds upon positive teacher capacity with the end results increasing student achievement.

As defined by Viduya (2000) leadership is both an activity and a process. It is an activity of influencing people to band together for a common purpose and endeavor by the inspiration and guidance of a leader determined to achieve this purpose. To be a leader, one must possess the talent and skills to be an effective leader. To be effective, one can exude a sincere image of an excellent leader.

Magda (2003) advocated that management expect always that "a good school administrator (principal or supervisor) as a leader of any school must learn appropriate skills". On the other hand, they forgot to say that a true leader, first and foremost must not only learn the skills but how to apply them correctly by being a justifiable example himself/herself. This is the correct interpretation of leadership by example which also means "learning the skills by doing". Interestingly, the skills of every leader in whatever school institution have become subjects for criticisms down the occupational ladder.

Therefore, a manager desiring to keep his job anticipating to move up the organizations ladder, must learn and continue to sharpen his leadership skills (Angeles, 2010). 
In previous days, the promotion of unqualified teachers to become "one of the leaders" had not been controlled - even if they were not qualified such as no board exams, no master studies in management, no appropriate skills as leaders, and so on. Nowadays, promotions become more regulated as a result of numerous competitions such as continuous professional advancement in the graduate school and other qualifications. To become one of the leaders in institution has caught much attention among our policy makers. The sole criterion which is the length of service is no longer applicable to promote teacher to a high level. Managing the school really needs certain leadership skills in order for the school administrators become efficient and effective.

Furthermore, in an era of rapid-educational change, the school administrator of today is faced with problems of such magnitude and diversity as to stagger the imagination of teacher's excessive tardiness, absenteeism, delay of submission of reports, pupil's drop-out, vandalism and the like. No longer will such administration and board of education rule with dictatorial power or adopt rules and regulations that encompass nearly every facet of the teacher's professional and personal life. Teachers and students are demanding voices in the operation of the school and are ready, willing and able to take to the street to emphasize their satisfaction.

Educational problems arise because the school, with school administrators providing leadership, has to initiate and promote educational change in response to social changes. In fact, identifying instructional leadership characteristics and skill among school administrators, leadership comes with a sense of urgency. This case may be true in Area III of Leyte Division where there are many school administrators who could be leaders in their districts but not all of them have the leadership skills. Some of them are not visible in their stations while others fail to conduct supervisory activity which is the most important role of a school administrator.

As the need for school leaders with competent and adequate leadership skills become the ultimate phenomenon among schools of today there is no doubt that school leaders have to be evaluated in order to figure out if they truly embody the type of leaders who can lead and are capable to address the problems faced by the schools, particularly on raising the quality of education offered to stakeholders and the same that the society expects from them.

Being a school administrator, the researcher is challenged to bring this issue to the fore and to look into this aspect particularly in the division of Leyte where she works and assumes as school administrator in a certain public secondary school. Consequently, it is in light of this perspective that this study is conceived and therefore the researcher opts to establish first-hand data and information which will somehow capacitate the Department of Education to consider the real causes of certain educational problems and to primarily consider the role and position of the school administrator thereat.

Results of this study are expected to draw the line in addressing the need among school administrators to be within the purview of what is called as sound and well-balanced school leadership.

\subsection{Objectives of the Study}

This study aimed to determine the leadership skills of school administrators in Area III Leyte Division. Specifically, it sought to attain the following objectives:

(1) Determine the profile of school administrators in Area III, Leyte Division in terms of age, sex, civil status, educational attainment, official designation, in service training attended, and length of administrative experience;

(2) Find out the effectiveness of school administrators' leadership skills in terms of setting instructional direction skills, teamwork skills, sensitivity skills, judgment skills, results orientation skills, organizational skills, oral communication skills, written communication skills, developing others, understanding own strength and weaknesses, decision making skills, human relation skills, tactful skills, directive skills, management skills, competency skills, motivational skills, observation skills and equality skills;

(3) Ascertain the school administrator's leadership behavior in Area III in Leyte Division in terms of framing the school goals, communicating the school goals, supervising and evaluating instruction, coordinating the curriculum, monitoring student progress, protecting instructional time, maintaining high visibility, providing incentives for teachers, promoting professional development, and providing incentives for learning;

(4) Determine the school performance in Area III Leyte Division;

(5) Find out the significant relationship between the profile of the school administrators and their leadership skills;

(6) Find out the significant relationship between the profile of the school administrators and their leadership behavior;

(7) Find out the significant relationship between the profile of the school administrators and the school performance;

(8) Find out the significant relationship between the school administrators' leadership skills and their leadership behavior; 
(9) Find out the significant relationship between the school administrators' leadership skills and school performance;

(10) Find out the significant relationship between the school administrators' leadership behavior and school performance; and

(11) Design an intervention scheme to improvethe leadership skills of the school administrators in Area III Leyte Division.

\subsection{Framework of the Study}

Theoretical framework. This study is anchored on the Leadership Theories by Treedy Heller (1982).He theorized that the essence of leadership is followership. It is the willingness of people to follow that makes a person a leader. Leaders must exercise all the functions of their role to combine human and material resources to achieve objectives. The Trait Theory as one assumes that the leader is conceived to be a "great man" whose superior endowments induce others to follow him and as a way of identifying the key characteristics of successful leaders. It was believed that through this approach critical leadership traits could be isolated and that people with such traits could then be recruited, selected and installed into leadership positions. This approach was common in the military and is still used as a set of criteria to select candidates for commissions.

Another theory which this study is anchored to is the Path-Goal Theory. This theory suggests that certain patterns of leader behavior facilitate the clarification of the group goals while other patterns of behavior stimulate effective instruments and response on the follower group.

The foregoing theories are concerned with the small subset of the total leadership problem. A complete theory of leadership should explain the emergence of leadership in initially unstructured groups; the maintenance of leadership once a role structure has been developed and stabilized; the relation of leader personality and behavior to follower and group response and the conditions under which specific patterns of leader personality and behavior are effective.

The theories cited above are relevant and indispensable to the present study because the concepts being illustrated relate to the variables treated in the present study on leadership skills.

Conceptual framework. The primordial concern of this study is to determine the leadership skills of school administrators in Area III Leyte Division.

The study measures the following parameters: profile of the school administrators in Area III Leyte Division; profile of teachers in Area III Leyte Division; leadership skills of the school administrator in Area III Leyte Division; school administrators in the areas of management; school performance in Area III Leyte Division. Significant relationships between variables are also determined. Figure 1 presents the conceptual framework of the study.

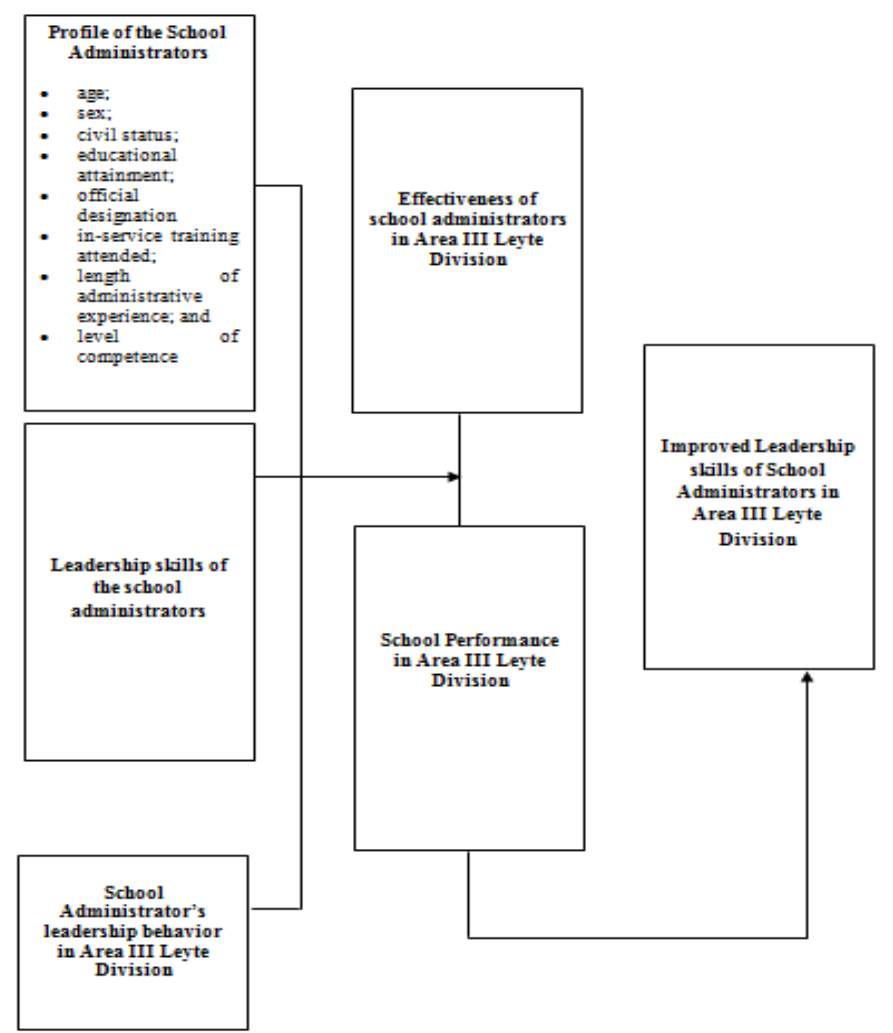

Figure 1.The Conceptual Framework of the Study 


\subsection{Scope and Delimitation of the Study}

The study carefully established certain limitations. For one, in terms of mode of data gathering, the researcher opted to, aside from the questionnaire, undertook personal interviews using semi-structured interview guide. In addition, only the leadership skills of the school administrators of Area III Leyte division were covered in this study. This was conducted in the school year 2015-2016.

\subsection{Review of Literature}

Baltazar et. al. (2004) advocated that to be a good manager, one has to have leadership capabilities. A good leader, though need not to be a good manager. There is a difference between a leader and a manager.

The leader is measured by how much influence he has in stimulating people to strive towards an objective. The manager is measured by how much influence he has in stimulating people to strive towards an objective. The manager is measured by how much he has attained an objective using not only humor resources but non-human resources (money, materials, methods, machines, or time) as well. Hence, a leader is a good leader because he can cause and direct people to move towards an objective. But he can be at the same time the lousiest manager because he is inefficient in the use of other resources. He does not have any coherent plan. He has the slightest idea of proper control and scheduling.

Koontz and O'Donnell (1981) as cited by Baltazar (2004) defined leadership as the "art of inducing subordinates to accomplish their assignments with zeal and confidence" and "the ability to persuade others to seek defined objectives enthusiastically".

Moreover, many scholars have devoted their time to studying leadership as one phenomenon that has the power to destroy our world. Current thinking has given both explanations credit in that leaders should have leadership qualities and he must, at the same time be at the right place at the right time. The debate over talent versus "luck" (right place, right time) of great leaders blossomed into a more methodical approach of explaining and describing what a leader is. By studying the characteristics of people who have been considered as leaders, researchers identified the following essential in the making of a leader. It was found out that intelligence and scholarship; physical traits; personality; social status and experience and task (or work) orientation.

Volumes of studies have been made but there apparently is no prices formula for shaping a leader. If at all studies indicated that traits are ingredients that combine and enhance or diminish a leader's effectiveness. The researchers failed to indicate what must be the proper mix of these traits and to what degree or amount each trait should combine with other traits. In sum, the traits approach to the study of leadership is but a scratch on the surface. There is still a need to deeper by examining other variables that affect leadership like the environment, the leader's inner qualities, the characteristics and force in the subordinates/followers, and other intangibles such as time.

While the trait approach describes what a leader is, another approach attempts to describe the leader by that he does-his style, his behavior. Dissatisfied with the many inconsistencies of the trait approach, latter-time researchers switched to the study of the behavior patterns or styles of leaders in trying to understand better the leadership phenomenon. Many of these researchers had the notion that there is "one best style" of leadership in every given organizational setting.

Manzanero (2003) stated that to maintain a productive school administrator must know how to be effective in the three areas of management. Leadership, staff development and human relations. A dynamic ad stimulating leadership of the school administrator is an important factor that affects teachers' job satisfaction, according to Hersberg. The quality of classroom output in a teaching learning process depends partly on the managerial ability and skill of the school administrator. If a manager is a good leader, he can influence the classroom teachers to be good also.

The school therefore, with the school administrator as a leader, should promote contentment among teachers who can effective and instrumental in providing quality education. He should lead his teachers to work together in translating the shared goals in functional and valuable experiences for school children. An administrator, no matter how good he is, cannot do the job by himself, he must create a situation wherein teachers will strive to do all they can their best un the implementation of the school's action plan following closely the time table for the whole year. Finally, he should be able to lead teachers toward the development of leadership potential.

On the other hand, Burr (2011) defined leadership in two basic elements. "What he/she is "refers to the leader's personal equipment, his/her personality character and competence. The "What he/she does" refers to his/her performance leadership styles/behavior.

Instructional leaders in their schools even could be seen as having a moral purpose to direct vision where the school for all children and youth by developing strong commitments to important things and modeling and supporting them continuously.

Elmore (2000) provides a unique perspective on the role of leadership. He agrees with those who promote instructional leadership in that he emphasizes the importance of understanding effective practices in 
curriculum, instruction, and assessment and the ability to work with teachers on the day-to-day and commitment. The human resource frame is based on the following set of assumptions: Firstly, organizations serve human needs such as physiological, social, self- esteem and self- actualization. Secondly, organizations and people need each other; organizations need skill, energy and ideas. Similarly, people need work opportunities, salaries and careers. Thirdly, either the organization or the people will suffer when the fit between the people and the organization is poor.

Sergiovanni (2007) indicates transactional leadership focuses on managerial skills such as rules, procedures, and job descriptions to accomplish expectations.

Likewise, Hughes (2006) states that school administrators' leadership style affects not only his way of doing things in the office but also the attitudes of teachers working with him. Hence, educational management also emphasizes that morale of teachers be kept at a high place. Considering that administrators and teachers are involved in almost all programs, it is necessary that the relationship be kept in an atmosphere of friendliness and mutual concern. The relationship of the school administrators and the teachers is of great importance for it affects the working climate under which the students learn.

Leadership skills have played an important role throughout the history. In fact, our quest today is for leaders who can effectively coordinate efforts to meet the challenges of a fast changing world. Effective teachers help organizations to develop a vision and mobilize the organization change towards the vision.

More recently, Bulach and Berry (2001) presented data using "The Instructional Improvement Survey" that measures four culture and seven climate factors. The instrument consists of 96 items and has an overall reliability of .91 as measured by Cronbach alpha. Reliability on each of the subscales varies from .79 to .85 .

Leadership behavior is measured in the following two culture and two climate factors: group atmosphere, group cooperation, instructional leadership, and discipline. Bulach and Peddie (2001) found a positive relationship (.96) between leadership behavior associated with instruction and the overall culture and climate of the school. Their study involved 20 schools and 1163 teachers.

Individualization of each teacher's professional growth plan is critical so that there is balance between required learning experiences, often linked directly with the district and/ or school improvement goals, as well as flexible learning opportunities that could include self-study, college credit work, on-site workshops, and ongoing professional learning. A teacher-evaluation system

Furthermore, Sergiovanni (2007) views the role of the school administrators as the instructional leader and transformational leadership as the style which best meets the needs of all stakeholders in the academic process. This approach advocates a shared leadership in which school administrators, along with faculty and staff, developing shared vision, using distributed leadership, and building a school culture which is necessary in restructuring efforts.

On the other hand, McEwan (2002) provided also a different perspective of leadership suggesting that there are seven steps to effective instructional leadership: 1.) establish clear instructional goals, 2) be there for your staff 3.)Create a school culture and climate conducive to learning,4.) Communicate the vision and mission of your school, 5.)Set high expectation, 6.) Develop teacher leaders; and 7.) Maintain positive attitudes toward students, staff and parents.

Zapeda (2003) viewed instructional leadership as instructional supervision aligned with classroom observations and professional development for teachers. In clinical supervision there are a pre-observation conference, observations, and post-observation. This cycle process also will be used to assess the teachers' performance.

As instructional leaders, school leaders should provide opportunities for teachers to work together on the basis of needs linked to what is observed by school leaders in classroom observation. Study groups, learning clusters and mentoring are some of the informal mechanisms for teachers to work together. On the basis of observations, school leaders can identify strengths and weaknesses of teachers, which lead to which teachers can serve as mentors and which teachers need mentors. Opportunities should also be provided for formalized professional development. Zapeda (2003).

In addition, the school administrator supports the evaluation process through ongoing feedback and time to talk about teaching. This type of professional learning system establishes common language for describing effective learning goals with students ( Blasé \& Blase, 1999, 2002; Blasé \& Kirby, 1992; Danielson \& McGreal,2000;Kimball,2002; Leithwood et al, 2010)

Cotton (2003) published the findings of her Book Principals and student Achievements focusing with the influence of principals leadership on student achievement, 10 dealt with the effect of principal leadership on student attitudes

Contingent rewards. Provenzo (2002) discovered also the three most important rewards for a teacher are as follows: opportunity to study, plan, master classroom management, reach and associate with students and colleagues (73\%); salary and respect and the position of influence (11.6\%); and economic security, time, freedom from competition $(11.6 \%)$. 
The school administrators/principals engages in frequent classroom observations and is highly accessible to faculty and staff. Good principals should also be a positive, vibrant and visible presence in the school. Modeling behaviors of learning, focusing on learning objectives, and leading by example are crucial to the success of instructional principal. He must possess the necessary leadership skills for efficiency and effectiveness in the attainment of global competitiveness. (Tan, 2014)

Angeles (2010) contented that there are certain characteristics traits that make a leader. A number of scholars/researchers have conducted several studies on leadership - as one phenomenon that has the power to create or destroy the world where one lives in. investigation revealed that great men became leaders because of it (leadership) was born with them. Others argued that these men just happened to be in the right place at the right time. Current thinking has given both leadership qualities. He must at the same time be at the right place and the right time but rarely is one born with the ability to lead.

Schneider (1992) as cited by Angeles (2010), asserted that leadership is a learned behavior. Given charisma is learned, she cited. Schneider claimed that through many may dream of leadership role, it is often dismissed as impossible. Leaders are often thought of as a single personality type - "born to lead" but in reality, according to her, all that leaders have in common is the initiative and the desire.

Stogdill (1974) as cited by Gosling and Dennison (2003) a well-known authority on organization management made a study on the characteristics of people who have been considered as leaders. His findings showed the following essentials in the making of a leader - 1.) Intelligence and scholarship, 2.) Physical traits, 3.) Personality, 4.) Social status and experience and 5.) Task/work orientation. He also identified the main leadership traits and skill as follows: The traits are: adaptable to situations, alert to social environment, ambitious and achievement - oriented, assertive, cooperative, decisive, dependable, dominant (desire to influence others) energetic (high activity level), persistent, self-confident, tolerant of stress and willing to assume responsibility. The skills are as follows: clever (intelligent) conceptually skilled, creative, diplomatic and tactful, fluent in speaking, knowledgeable about group task, organized (administrative ability) persuasive and socially skilled.

Finally, Delos Santos (2002) as further cited by Angeles (2010) categorized certain outstanding traits of leaders in the military organization. These leadership characteristics are "shakers" and "movers". He said that leaders tend to achieve significant mile - stones and passionately pursue their mission if the subordinate are to lead their lives with a sense of destiny. They can stay on course and develop patterns of excellence and achievement.

Studies relevant with the matter have been made but there apparently is no precise formula for shaping a leader. If at all, studies indicated that traits are ingredients that combine and enhance or diminish a leader's effectiveness. In fact, the researcher undertaken failed to indicate what be the proper mix of these traits and to what degree or amount each trait should combined with other traits. The trait approach to the study of leadership is just a scratch on the surface. There is still a need to go deeper by examining other variables that affect leadership like the environment, the leader's inner qualities, the characteristics and forces in the subordinates/followers and other intangibles such as time.

While the trait approach describes what a leader is, another approach attempts to describe the leader by what he does - his style, his behavior. Latter -time researchers have switched interest in trying to understand better the leadership phenomenon. Many of these researchers developed the idea that there is "one best style of leadership in every give organizational setting". The behavioral researchers/theorist suggest that a leader's style could either be employee - centered or job's centered. The former style emphasizes concern over the welfare, harmony, well-being and sensitivity to the needs of employees or subordinate to the needs of employees or subordinate. In contrast, a job - centered style is more concerned with completing the job as scheduled or as specified through proper planning and application of appropriate managerial/techniques.

Desamito (2010) explained what it takes to be a leader. Leadership consists of these parts. The first is to have a vision or an objectives or a goal. The second is to articulate that goal to other members of your team and to $\mathrm{a}=$ obtain their commitment to that objectives. The third is to develop and implement a plan to attain that goal. Not everyone is taught to be a leader, whether directly or from the side. Good leadership is the effect of the careful application of these skills. Setting an example is probably the most important leadership skill.

Everyday leaders or school administrators must make decision in order to attain their institutions vision and mission (Dela Cruz, 2010). Likewise, leadership is earned through building good relationship with people. The formula to success is to know how to get along with people by making every person you meet feel needed, important and appreciated or treat him as the most important person on earth.

What the world needs now is moral leadership. Being in power does not make one a leader and the most fit to govern are not always in politics. Here are the ten sign of leadership as shared by bestselling author and motivational guro John C. Maxwella as stressed by Aquino (2007). 1.) Character. The first sign of leadership is character. A leader has integrity and moral convictions. He inspires trust because of his word - of honor and grace under pressure; 2.) Influence. The sign of leadership is positive influence on others. A leader 
can make things happen. He is a moral force for good; 3.) Attitude. The third sign of leadership is a positive attitude. A leader knows he will triumph in the end no matter what happen because what he is doing is right. He always knows what is right and what is wrong - and he will never violate his conscience just for expediency; 4.) People Skills. The fourth sign of leadership is excellent people skills. a leader understand what the other person is feeling. He has genuine concern for the welfare. 5.) Talents. The fifth sign of leadership is the possession of evident talents. A leader has something to offer. He can contribute significantly to enhance the world; 6.) Track Record. The sixth sign of leadership is the possession of a good track record. A leader leaves a mark in the world. His achievements, however small, reflect those ideas to which all decent men aspire; 7.) Confidence. The seventh sign of leadership is the ability to instill confidence in others. A leader brings out the best in people. He inspires other to achieve their dreams. 8.) Discipline. The eight sign of leadership is self-discipline. A leader is in full control of his sense. His actions are consistent with his goals; 9.) Communication. The ninth sign of leadership is the possession of effective communication skills. A leader can connect directly to people in the gut level. His stand on issue is clear and categorical; 10.) Discontent. The tenth sigh of leadership is discontent with the status quo. A leader is visionary. He lives for a higher purpose and wants others to discover that freedom.

Actions of the principal can have widespread impact on many students. Effective educational leadership makes a difference in improving student learning (Leithwood \& Jantzi, 2000; Nettles \& Herrington, 2007). While there is evidence that a relationship between principal behavior and student achievement exists, it is unclear which specific principal behaviors contribute to increased student learning. Because causal relationships are unclear, researchers' focus on the direct effect of principal behavior on student learning has been replaced by a focus on the overall influence principals' behavior has on student achievement through their interaction with teachers and the school environment (Nettles \& Herrington, 2007; Witziers, Bozkers, \& Kruger, 2003). This section reviews the literature focusing on the overall influence of principal leadership on student achievement.

Many researchers have described the traits of an effective instructional leader (Heck et al., 1990; Nettles \& Herrington, 2007; Marzano, Waters, \& McNulty, 2005; Saphier, King, \& D'Auria, 2006); several factors are common in the general literature on important traits of an effective leader. Blasé and Blasé (2000) assert that effective school leadership must include the principal in the role of the instructional leader. An instructional leader must: (a) give feedback, (b) model effective instruction, (c) solicit opinions, (d) make suggestions, (e) support collaboration, (f) provide professional development opportunities, and (g) give praise for effective teaching (Blasé \& Blasé, 2000).

Stakeholder involvement as a descriptor of effective school leadership involves the principal's ability to (a) build leadership capacity in teachers and staff, (b) encourage team focus on school goals, (c) use efficient and flexible organizational skills, and (d) distribute leadership throughout the school (Rea, McLaughlin, \& Walther-Thomas, 2002).

High expectations for student performance held by the principal are an important component of effective school leadership. Consistently communicating expectations to students has been correlated with increasing student achievement in schools (Leithwood \& Jantzi, 2000). Hand in hand with high expectations for students, effective principals also have high expectations for staff; effective school leaders expect teachers to put student achievement before all else and focus time management toward instructional priorities (Nettles \& Herrington, 2007). Hoy and Hannum (1997) refer to this high expectation for performance as collegial influence. Finally, professional development is an area that has been heavily researched and supported in that much of a principal's success comes from the opportunities the principal provides for the staff (Dufour \& Berkey, 1995; Leitner, 1994; Nettles \& Herrington, 2007).

The leadership of the principal affects, either positively or negatively, the learning and working environment of students and teachers (Pepper \& Thomas, 2002). Principal support influences the feelings teachers have about themselves and their work. Teachers characterizing principals as supportive (a) found work more rewarding (b) enjoyed a more productive and motivating work environment, (c) demonstrated lower turnover rates, and (d) experienced lower job-related stress and burn-out. Consequently, these factors may have affected how successful their students were.

The principal has the power to establish and guide the positive progress of a school and develop and nurture relationships within the school community that impact the overall school climate (Day, 2000; Pepper \& Thomas, 2002). The principal must establish an atmosphere of trust and camaraderie, as opposed to an atmosphere of competition and confrontation. Principals and teachers should interact in such a way that demonstrates mutual respect and caring, a relationship the students will witness and hopefully learn from.

There are several strands of literature concerned with the relationships between principal characteristics and school performance. One set of studies relates raw test scores to principal characteristics (Blank 1987; Eberts and Stone 1988; Heck, Larsen, and Marcoulides 1990; Brewer 1993; Heck and Marcoulides 1993; Hallinger and Heck 1996; Waters, Marzano, and McNulty 2003; Witziers, Bosker, and Kruger 2003). These studies are limited in that they consider only a narrow range of principal characteristics, use only a small sample 
of schools, and do not adequately control for factors that confound the relationship between achievement and principal characteristics such as student demographics. A second strand of this literature examines other studentbased outcomes such as attendance (Blank 1987) and student engagement (Leithwood and Jantzi 1999). These outcomes are also likely to be strongly influenced by student composition, making it difficult to draw conclusions from these studies without strong identification assumptions. Moreover, it is also unclear whether these measures represent inputs or outputs.

A third strand of the literature measures school performance using teacher-based outcomes such as teachers' evaluations of school principal performance (Ballou and Podgursky 1993) and teacher 6 mobility/attrition (Gates et al. 2006). Teacher ratings can overcome some of the limitations of studentbased measures, to the extent that teachers are aware of factors such as the socio-economic background of the study body, but these evaluations are subjective, and may not be strongly related to student outcomes. These three sets of papers generate mixed evidence in regards to the relationship between school performance and principal characteristics. In terms of principal education, both Eberts and Stone (1988) and Ballou and Podgursky (1993) find a negative correlation between school performance and principal education, as measured by advanced degrees and graduate training. One explanation, advanced by Eberts and Stone (1988), is that highly-educated principals are placed in low-performing schools.

Both Eberts and Stone (1988) and Ballou and Podgursky (1993) find a positive association between years of teaching experience and school performance although Brewer (1993) finds no such correlation. Evidence on the impacts of principal experience is also mixed: Eberts and Stone (1988) find positive effects while Ballou and Podgursky (1993) find no correlation. These mixed results could reflect differences across outcomes, controls, or sample characteristics. None of these studies have addressed whether principals that participated in training programs improve school performance, in part because these programs are a relatively recent phenomenon. This paper constitutes a fourth strand of this literature, one that analyzes these relationships using detailed administrative principal data matched to detailed administrative student data. To our knowledge, only Branch, Hanushek, and Rivkin (2008) have conducted a similar analysis. Focusing on Texas, they document changes in the composition of principals and patterns of principal mobility. They then estimate school performance models that include student characteristics and school characteristics, principal and school fixed effects and principal experience and tenure. Their interest is in the relationship between principal mobility and principal effectiveness (as measured by the estimated principal fixed effects) and in the relationship between principal experience and school performance. We return to their findings in Section 6, and compare their results with our own.

Three recent papers have addressed more specific questions relating to principals. Coelli and Green (2009) estimate the variation in principal effectiveness across schools. Their approach-a version of the method Rivkin, Hanushek, and Kain (2005) use to analyze teacher impacts-ignores specific principal characteristics such as education and experience and focuses instead on the correlation between within-school performance variation and within-school principal turnover: under some assumptions, the strength of this correlation is increasing in the variation in principal effectiveness. One important assumption is that student sorting is unrelated to principal effectiveness. If that assumption is violated (e.g., if effective principals attract highachieving students to a school), this method will overstate the variation in principal effectiveness. Their results suggest some role for principal quality in determining students' standardized exam scores, but they find little impact on graduation rates. Cullen and Mazzeo (2008) examine the relationship between school performance and the principal's future wages. They find that strong performance is associated with increased future wages, which suggests that the principal labor market may provide effective incentives for principals. Finally, Corcoran, Schwartz, and Weinstein (2009) evaluate the NYC Aspiring Principals Program discussed above. They find evidence that APP principals enter schools whose performance is on the decline, and that they improve school performance on standardized tests, particularly in English, after about three years. We discuss this study in more detail below after presenting our findings relating to the APP program.

The foregoing review of literature and related studies are significantly related to the present study as information and ideas contained deal with the variables indicated in the study particularly on the subject school leadership.

\section{Methodology}

The study employed the descriptive-correlational research design as the main technique focusing on the leadership skills and behaviors of school administrators in Area III Leyte Division. It is the most appropriate design for this study because it applies mainly description of certain phenomena and application of empirical data on the variables treated in this study.

The venue of the study is in Area III Leyte Division which comprises the following: Calubian North and South Districts, Tabango North and South Districts, Leyte I and Leyte II Districts, San Isidro District, and Villaba North and South Districts. 
The respondents included 110 school administrators. There are about 110 schools in the area of which the total school administrators were taken. Following the selection process, the principals/school heads constitute 85 percent of the population while the other 15 percent comes from the teacher population.

The research instrument is a survey questionnaire made up of several sections. Part I covers the profile of the school administrator-respondents which contain the official designation, age, sex, civil status, highest educational attainment, length of administrative experience level of competence and in-service training attended. Part II highlights the leadership skills of school administrators which cover the following components: decision-making skills, human relation skills, tactful skills, directive skills, management skills, competency skills, motivational skills, commitment skills, observation skills and equality skills. Part III features the leadership behavior of school administrators with components on making suggestions, giving feedback, modelling effective instruction, soliciting opinions, supporting collaboration and providing professional development opportunities. Part IV concerns on the effectiveness of school administrators.

The descriptive statistics such as frequency, counts, percentage and mean were applied in the statistical analysis of the data.

\section{Results and Discussion}

\subsection{Profile of the School Adminisrators}

The socio-demographic profile of the school administrators was categorized into age, sex, civil status, educational attainment, in-service training attended and length of administrative experience. This is presented in Table 1.

Table 1: Profile of the School Administrators

\begin{tabular}{|l|l|l|}
\hline Age & f & \% \\
\hline 60 and above (senior citizen) & 3 & 2.7 \\
\hline $46-59$ (old age) & 62 & 56.4 \\
\hline $22-45$ (middle-aged) & 45 & 40.9 \\
\hline 21 and below (young) & 0 & 0 \\
\hline Total & $\mathbf{1 1 0}$ & $\mathbf{1 0 0 . 0 0}$ \\
\hline Sex & $\mathbf{f}$ & $\mathbf{\%}$ \\
\hline Male & 44 & 40.00 \\
\hline Female & 66 & 60.00 \\
\hline Total & $\mathbf{1 1 0}$ & $\mathbf{1 0 0 . 0 0}$ \\
\hline Civil Status & $\mathbf{f}$ & $\mathbf{\%}$ \\
\hline Single & 16 & 14.5 \\
\hline Married & 83 & 75.5 \\
\hline Annulled & 1 & .90 \\
\hline Separated & 3 & 2.7 \\
\hline Widow/widower & 7 & 6.4 \\
\hline Total & $\mathbf{1 1 0}$ & $\mathbf{1 0 0 . 0 0}$ \\
\hline
\end{tabular}

\begin{tabular}{|c|c|c|}
\hline Highest Educational Attainment & $\mathbf{f}$ & $\%$ \\
\hline Doctorate Degree Holder & 8 & 7.3 \\
\hline Masters Degree with Doctoral Units & 22 & 20.0 \\
\hline Masters Degree Holder & 46 & 41.8 \\
\hline BS Degree with Masteral Units & 34 & 30.9 \\
\hline Total & 110 & 100.00 \\
\hline Official Designation & f & $\%$ \\
\hline Principal I & 39 & 35.5 \\
\hline Principal II & 10 & 9.1 \\
\hline Head Teacher I & 13 & 11.8 \\
\hline Head Teacher II & 9 & 8.2 \\
\hline Head Teacher III & 37 & 33.6 \\
\hline Master Teacher & 2 & 1.8 \\
\hline Total & 110 & 100.00 \\
\hline Local Trainings & f & $\%$ \\
\hline 10 and above & 49 & 44.5 \\
\hline $7-9$ times & 8 & 7.3 \\
\hline $4-6$ times & 31 & 28.2 \\
\hline 1-3 times & 14 & 12.7 \\
\hline none & 8 & 7.3 \\
\hline Total & 110 & 100.00 \\
\hline Regional Trainings & f & $\%$ \\
\hline 10 and above & 5 & 4.5 \\
\hline $7-9$ times & 7 & 6.4 \\
\hline 4-6 times & 34 & 30.9 \\
\hline $1-3$ times & 50 & 45.5 \\
\hline none & 14 & 12.7 \\
\hline
\end{tabular}


Effectiveness of School Administrators' Leadership Skills and Behaviors and their School...

\begin{tabular}{|l|l|l|}
\hline Total & $\mathbf{1 1 . 0}$ & $\mathbf{1 0 0 . 0 0}$ \\
\hline National Trainings & $\mathbf{f}$ & $\mathbf{\%}$ \\
\hline 10 and above & 0 & 0 \\
\hline $7-9$ times & 0 & 0 \\
\hline $4-6$ times & 8 & 7.3 \\
\hline $1-3$ times & 47 & 42.7 \\
\hline none & 55 & 50.0 \\
\hline Total & $\mathbf{1 1 0}$ & $\mathbf{1 0 0 . 0 0}$ \\
\hline International Trainings & $\mathbf{f}$ & $\mathbf{\%}$ \\
\hline 10 and above & 0 & 0 \\
\hline $7-9$ times & 0 & 0 \\
\hline $4-6$ times & 1 & 0.9 \\
\hline $1-3$ times & 11 & 10.0 \\
\hline none & 98 & 89.1 \\
\hline Total & $\mathbf{1 1 0}$ & $\mathbf{1 0 0 . 0 0}$ \\
\hline Length of Administrative & $\mathbf{f}$ & $\mathbf{\%}$ \\
\hline Experience & & 11.8 \\
\hline 20 years and above & 13 & 16.4 \\
\hline $15-19$ years & 18 & 23.6 \\
\hline $10-14$ years & 26 & 48.2 \\
\hline 9 years and below & 53 & $\mathbf{1 0 0 . 0 0}$ \\
\hline Total & $\mathbf{1 1 0}$ & \\
\hline
\end{tabular}

Age. As viewed from the table, majority of the respondents with a frequency of $62(56.4 \%)$ were oldage. The other bigger in number with a frequency of $45(40.9 \%)$ were middle-age. Only less with a frequency of three $(2.7 \%)$ were senior citizens. The opportunity of becoming a school administrator depends also on the age factor that is why many are usually in the old age which implies that the older someone is in the service the longer he/she serves. Similarly, since 65 is the compulsory retirement age, it is normal that many would reach the old age for school administrators.

Sex. More than half of the respondents with a frequency of $66(60 \%)$ were female and the remaining half with a frequency of $44(40 \%)$ were male. Female school administrators ruled out against the female ones. This implies that with gender and development any sex can penetrate into the position as much as gender equality is now being recognized.

Civil status. The dominant are married school administrators with a frequency of 83 (75.5\%). The singles were second with a frequency of $16(4.5 \%)$. There are also those who were annulled, separated, widow/widower although least in number. It is expected that the married ones dominated in number since they are within marrying ages.

Highest educational attainment. The masters' degree holders constituted the bigger number of respondents with a frequency of $46(41.8 \%)$. At a close second were the BS degree holders with masters' units with a frequency of $34(30.9 \%)$. Only few obtained doctorate degrees with a frequency of $8(7.3 \%)$. Although many of the school administrators are typically in better educational attainment, they still have greater room for improvement by pursuing doctorate studies.

Official designation. Principal I topped with a frequency of 39 (35.5\%); Head Teacher III is second with a frequency of $37(33.6 \%)$. Master Teacher is the least with a frequency of $2(1.8 \%)$. Many are Principal I since the respondents are qualified although in some instances the designation is based on the discretionary power of the head but they, too, should at least possess the minimum qualification requirements.

Trainings attended. Many of the school administrators have availed mostly of local and regional trainings. Nearly half of them have attended trainings in the national level and, interestingly, there was about ten percent who made it in international level. This shows that Leyte Division is supportive of its school administrators. An implication can also be drawn that they may still continue the culture of sending the school administrators to other trainings especially in the national and international levels.

Length of administrative experience. The longest serving respondents with a frequency of 53 (48.2\%) were those in the bracket 9 years and below. Those in the next rank were those serving 10-14 years with a frequency of $26(23.6 \%)$. The third were those 15-19 years and above with a frequency of 18 (16.4\%). Only thirteen (11.8\%) served the longer at 20 years and above. This implies that most of the respondents are not that longer in the position as school administrators. This can also be supported with the data shown in their age.

\section{Effectiveness of School Administrators in Leadership Skills}

The effectiveness of leadership skills was gauged through various components such as setting instructional direction skills, teamwork skills, sensitivity skills, judgment skills, results orientation skills, organizational skills, oral communication skills, written communication skills, and understanding own strengths and weaknesses. These are given emphasis through discussions in the following tables below. 
Effectiveness of School Administrators' Leadership Skills and Behaviors and their School...

Table 2: Effectiveness of School Administrators in Leadership Skills(Setting Instructional Direction Skills)

\begin{tabular}{|c|c|c|}
\hline Indicators & WM & Description \\
\hline $\begin{array}{c}\text { The School Administrator articulates a clear vision } \\
\text { for the school and its effort related to teaching and leaming. }\end{array}$ & 4.05 & Highly Effective \\
\hline $\begin{array}{c}\mathrm{He} / \text { she sets high performance expectations related to } \\
\text { teaching and leaming for self and others. }\end{array}$ & 4.09 & Highly Effective \\
\hline $\begin{array}{c}\mathrm{He} / \text { she encourages innovation to improve teaching } \\
\text { and successfulleaming for every student. }\end{array}$ & 4.11 & Highly Effective \\
\hline $\begin{array}{c}\mathrm{He} / \text { she sets measurable objectives for student } \\
\text { academic success and effective instruction. }\end{array}$ & 4.01 & Highly Effective \\
\hline $\begin{array}{c}\mathrm{He} / \text { she generates enthusiasm and persuades others to } \\
\text { work together to accomplish common goals for the success of } \\
\text { every student. }\end{array}$ & 4.06 & Highly Effective \\
\hline $\begin{array}{c}\mathrm{He} / \text { she develops alliances and resources outside the } \\
\text { school to improve the quality of teaching andleaming. }\end{array}$ & 3.92 & Highly Effective \\
\hline $\begin{array}{c}\mathrm{He} / \text { she clearly articulates the performance of others } \\
\text { regarding the performance of others as it relates to effective } \\
\text { instruction and student success. }\end{array}$ & 3.94 & Highly Effective \\
\hline $\begin{array}{c}\mathrm{He} / \text { she acknowledges and celebrates the } \\
\text { achievements and accomplishments of others in their efforts to } \\
\text { ensure student success. }\end{array}$ & 4.04 & Highly Effective \\
\hline $\begin{array}{c}\text { He/she seeks commitment of all involved to a specific } \\
\text { course of action to improve student leaming }\end{array}$ & 4.02 & Highly Effective \\
\hline AlwM & 4.08 & Highly Effective \\
\hline
\end{tabular}

Setting instructional direction skills. With an Average Weighted Mean of 4.08 tagged as Highly Effective, the school administrators demonstrated to be highly effective in setting instructional direction skills. The respondents exert enough effort and utilize available resources to steer their schools into the right direction. This implies that they put teaching and learning their greatest priority which is reflective of effective instruction and improved academic achievement of the learners.

Teamwork skills. The school administrators manifested high effectiveness in teamwork skills as marked by the Average Weighted Mean of 4.12 interpreted as Highly Effective. The results are proof of the smooth and healthy working relationships built by school administrators with their faculty and subordinates through their being supportive to the team, open-mindedness for better ideas, assistive and supportive in the operation of the schools and for valuing consensus. This means that the school administrators believe in the capacity of their people and consider them to be important assets to the organization in such a way that they are being involved in all endeavors towards school development.

Table 3: Effectiveness of School Administrators in Leadership Skills(Teamwork Skills)

\begin{tabular}{|c|c|c|}
\hline Indicators & WM & Description \\
\hline $\begin{array}{c}\text { The School Administrator supports the ideas and } \\
\text { views offered by team members to resolve problems and } \\
\text { improve student learning. }\end{array}$ & 4.19 & Highly Effective \\
\hline $\begin{array}{c}\text { He/she encourages other to share ideas and } \\
\text { opinions regarding improved teaching and learning. }\end{array}$ & 4.14 & Highly Effective \\
\hline $\begin{array}{c}\text { He/she contributes his/her ideas toward reaching } \\
\text { solutions and improving student success. }\end{array}$ & 4.14 & Highly Effective \\
\hline He/she assists in the operational task of the team. & 4.16 & Highly Effective \\
\hline $\begin{array}{c}\text { He/she seeks input from team members regarding } \\
\text { ideas to improve learning. }\end{array}$ & 4.06 & Highly Effective \\
\hline $\begin{array}{c}\text { He/she assists the team in maintaining the } \\
\text { direction needed to complete the tasks. } \\
\text { He/she seeks to develop consensus among team } \\
\text { members. }\end{array}$ & 4.06 & Highly Effective \\
\hline AWM & 4.12 & Highly Effective \\
\hline
\end{tabular}

Sensitivity skills. Posting an Average Weighted Mean of 4.02 labeled as Highly Effective, the school administrators were highly effective in terms of their sensitivity skills. The respondents are known for their abilities to feel the emotions and feelings of others and tend to value these by being tactful and trying to middle sticky situations to work out positively for both parties. This suggests that the school administrators respond maturely and properly to the needs of their people and prevailing situations by being sensitive of what works best and what not. 
Table 4: Effectiveness of School Administrators in Leadership Skills(Sensitivity Skills)

\begin{tabular}{|c|c|c|}
\hline Indicators & WM & Description \\
\hline $\begin{array}{l}\text { The School Administrator interacts appropriately } \\
\text { and tactfully with people from different backgrounds }\end{array}$ & 3.95 & Highly Effective \\
\hline $\begin{array}{l}\mathrm{He} / \mathrm{she} \text { elicits perceptions, feelings and concerns } \\
\text { of others }\end{array}$ & 4.0 & Highly Effective \\
\hline $\begin{array}{l}\text { He/she voices disagreement without creating } \\
\text { unnecessary conflict. }\end{array}$ & 3.91 & Highly Effective \\
\hline $\begin{array}{l}\mathrm{He} / \text { she anticipates responses of others and acts to } \\
\text { reduce negative impact. }\end{array}$ & 4.02 & Highly Effective \\
\hline $\begin{array}{l}\mathrm{He} / \mathrm{she} \text { communicates necessary information to } \\
\text { the appropriate persons in a timely manner. }\end{array}$ & 4.14 & Highly Effective \\
\hline $\begin{array}{l}\text { He/she expresses verbal or non-verbal } \\
\text { recognition of feelings, needs and concerns of others. }\end{array}$ & 4.08 & Highly Effective \\
\hline $\begin{array}{l}\text { He/she responds tactfully to others in emotionally } \\
\text { stressful situations or in conflict. }\end{array}$ & 4.04 & Highly Effective \\
\hline $\mathrm{He} /$ she takes action to divert unnecessary conflict. & 4.04 & Highly Effective \\
\hline $\begin{array}{l}\mathrm{He} / \mathrm{she} \text { responds in a timely manner to others who } \\
\text { initiate contact with him or her. }\end{array}$ & 4.05 & Highly Effective \\
\hline AWM & 4.02 & Highly Effective \\
\hline
\end{tabular}

Table 5: Effectiveness of School Administrators in Leadership Skills(Judgment Skills)

\begin{tabular}{|c|c|c|}
\hline Indicators & WM & Description \\
\hline $\begin{array}{l}\text { The School Administrator assigns priority issues } \\
\text { and tasks within the school's vision for teaching and } \\
\text { learning. }\end{array}$ & 4.12 & Highly Effective \\
\hline $\begin{array}{l}\mathrm{He} / \mathrm{she} \text { exercises caution when dealing with } \\
\text { unfamiliar issues and individuals. }\end{array}$ & 3.96 & Highly Effective \\
\hline $\begin{array}{l}\text { He/she avoids reaching quick conclusions and } \\
\text { making decisions with limited data. }\end{array}$ & 3.92 & Highly Effective \\
\hline $\begin{array}{l}\mathrm{He} / \mathrm{she} \text { evaluates information to determine the } \\
\text { elements that affect teaching and learning. }\end{array}$ & 3.99 & Highly Effective \\
\hline $\begin{array}{l}\mathrm{He} / \mathrm{she} \text { communicates a clear learning-related } \\
\text { rationale for each decision. }\end{array}$ & 4.00 & Highly Effective \\
\hline $\begin{array}{l}\mathrm{He} / \mathrm{she} \text { seeks additional information about issues } \\
\text { and events related to the school and its mission. }\end{array}$ & 4.06 & Highly Effective \\
\hline $\begin{array}{l}\mathrm{He} / \text { she uses relevant sources for data and } \\
\text { information to confirm or refute assumptions. }\end{array}$ & 4.04 & Highly Effective \\
\hline $\begin{array}{l}\mathrm{He} / \mathrm{she} \text { asks follow-up questions to clarify } \\
\text { information. }\end{array}$ & 4.11 & Highly Effective \\
\hline He/she seeks to identify causes of problems & 4.13 & Highly Effective \\
\hline $\begin{array}{l}\text { He/she establishes relationship between issues } \\
\text { and events. }\end{array}$ & 4.03 & Highly Effective \\
\hline AWM & 4.04 & Highly Effective \\
\hline
\end{tabular}

Judgment skills. It is shown that the school administrators were highly effective in their judgment skills as supported by the Average Weighted Mean of 4.04 interpreted as Highly Effective. It is imperative that the school administrators have sound, strong and positive judgment skills and they are likewise determined regarding the rationality of coming up with decisions. This further implies that they possess excellent judgment skills.

Table 6: Effectiveness of School Administrators in Leadership Skills(Results Orientation Skills)

\begin{tabular}{|c|c|c|}
\hline Indicators & WM & Description \\
\hline $\begin{array}{c}\text { The School Administrator takes action to move } \\
\text { issues toward closure in a timely manner. }\end{array}$ & 4.02 & Highly Effective \\
\hline $\begin{array}{c}\text { He/she takes responsibility for implementing } \\
\text { initiatives to improve teaching and learning. }\end{array}$ & 4.09 & Highly Effective \\
\hline $\begin{array}{c}\text { He/she determines criteria that indicate a problem } \\
\text { or issues are resolved. }\end{array}$ & 3.99 & Highly Effective \\
\hline $\begin{array}{c}\text { He/she considers the long-term or short-term } \\
\text { implications of a decision on teaching and learning before } \\
\text { taking action }\end{array}$ & 3.95 & Highly Effective \\
\hline $\begin{array}{c}\text { He/she sees the big picture related to student } \\
\text { learning as the mission of the school. }\end{array}$ & 3.98 & Highly Effective \\
\hline AWM & $\mathbf{4 . 0 1}$ & Highly Effective \\
\hline
\end{tabular}

Results orientation skills. With an Average Weighted Mean of 4.01 known as Highly Effective, the school administrators were exceptional in results orientation skills. It is illustrated that the school administrators 
are action-driven, responsible, and committed to accomplishing something greater than what actually the organization has actually set as its vision and mission.

Table 7: Effectiveness of School Administrators in Leadership Skills(Organizational Skills)

\begin{tabular}{|c|c|c|}
\hline Indicators & WM & Description \\
\hline $\begin{array}{c}\text { The School Administrator delegates } \\
\text { responsibility to others. }\end{array}$ & 4.01 & Highly Effective \\
\hline $\begin{array}{c}\text { He/she monitors the progress and } \\
\text { completion delegated responsibilities. }\end{array}$ & 4.04 & Highly Effective \\
\hline $\begin{array}{c}\text { He/she develops action plans to achieve } \\
\text { goals related to student learning. }\end{array}$ & 3.93 & Highly Effective \\
\hline $\begin{array}{c}\text { He/she monitors progress and modifies } \\
\text { plans or actions as needed. }\end{array}$ & 4.03 & Highly Effective \\
milestones. & 4.00 & Highly Effective \\
\hline He/she prepares effectively for meetings. & 4.1 & Highly Effective \\
\hline $\begin{array}{c}\text { He/she uses available resources effectively } \\
\text { to accomplish the student learning goals of the school. }\end{array}$ & 4.15 & Highly Effective \\
\hline AWM & $\mathbf{4 . 0 4}$ & Highly Effective \\
\hline
\end{tabular}

Organizational skills. The school administrators were highly effective as to their organizational skills as shown in the Average Weighted Mean of 4.04 interpreted as Highly Effective. They tend to exhibit noteworthy organizational skills by practicing delegation, setting plans and actions, and effectively using available resources.

Table 8: Effectiveness of School Administrators in Leadership Skills(Oral Communication Skills)

\begin{tabular}{|c|c|c|}
\hline Indicators & WM & Description \\
\hline $\begin{array}{c}\text { The School Administrator demonstrates effective } \\
\text { presentation skills, e.g., opening and closing comments, eye } \\
\text { contact, enthusiasm, confidence, rapport. }\end{array}$ & 4.09 & Highly Effective \\
\hline He/she speaks articulately. & 3.96 & Highly Effective \\
\hline He/she uses correct grammar. & 3.91 & Highly Effective \\
\hline $\begin{array}{c}\text { He/she tailors messages to meet the needs of each } \\
\text { unique audience. }\end{array}$ & 3.96 & Highly Effective \\
\hline $\begin{array}{c}\text { He/she clearly presents thoughts and ideas in one- } \\
\text { on-one conversations. }\end{array}$ & 3.95 & Highly Effective \\
\hline $\begin{array}{c}\text { He/she clearly presents thoughts and ideas in } \\
\text { communication with small groups. }\end{array}$ & 4.02 & Highly Effective \\
\hline $\begin{array}{c}\text { He/she clearly presents thoughts and ideas in } \\
\text { formal, larger group presentations. }\end{array}$ & 3.94 & Highly Effective \\
\hline AWM & $\mathbf{3 . 9 6}$ & \\
\hline
\end{tabular}

Oral communication skills. The school administrators displayed highly effective oral communication skills as evident of the Average Weighted Mean of 3.96 interpreted as Highly Effective. This tells that the school administrators speaks well and is proficient with the language. The data implies that they have a good command of the language and they are sources of bright ideas and thoughts.

Table 9: Effectiveness of School Administrators in Leadership Skills(Written Communication Skills)

\begin{tabular}{|c|c|c|}
\hline Indicators & WM & Description \\
\hline The School Administrator writes concisely & 3.98 & Highly Effective \\
\hline He/she demonstrates technical proficiency in & 3.89 & Highly Effective \\
\hline He/she expresses ideas clearly in writing. & 3.88 & Highly Effective \\
\hline $\begin{array}{c}\text { He/she writes appropriately for each of the } \\
\text { different audiences in the school community. }\end{array}$ & 3.98 & Highly Effective \\
\hline AWM & $\mathbf{3 . 9 3}$ & Highly Effective \\
\hline
\end{tabular}

Written communication skills. Posting an Average Weighted Mean of 3.93, the school administrators exhibited highly effective written communication skills. The result shows that the school administrators express their ideas fully well in writing and are able to connect to their respective audiences.

Developing others skills. It can be seen that the school administrators were highly effective in developing others skills as marked by an Average Weighted Mean of 4.04. This means that the school administrators contend the resolve to help develop others in many ways particularly in professional aspects for the attainment of student learning. 
Table 10: Effectiveness of School Administrators in Leadership Skills(Developing Others Skills)

\begin{tabular}{|c|c|c|}
\hline Indicators & WM & Description \\
\hline $\begin{array}{c}\text { The School Administrator shares information and } \\
\text { expertise from his/her professional experiences to assist the } \\
\text { professional growth of others. }\end{array}$ & 4.10 & Highly Effective \\
\hline $\begin{array}{c}\text { He/she motivates others to change behaviors that } \\
\text { inhibit their professional growth and student learning. }\end{array}$ & 4.09 & Highly Effective \\
\hline $\begin{array}{c}\text { He/she suggests specific developmental activities } \\
\text { to improve other's professional capacity to contribute to } \\
\text { student learning. }\end{array}$ & 4.02 & Highly Effective \\
\hline $\begin{array}{c}\text { He/she gives behaviorally-specific feedback } \\
\text { focusing in behaviors, not the person. }\end{array}$ & 4.05 & Highly Effective \\
\hline $\begin{array}{c}\text { He/she asks a protégé what he/she perceives to be } \\
\text { strengths and weaknesses and what he/she wants to improve. }\end{array}$ & 3.97 & Highly Effective \\
\hline $\begin{array}{c}\text { He/she seeks agreement on specific actions to be } \\
\text { taken by a protégé for his/her development and growth. }\end{array}$ & 3.98 & Highly Effective \\
\hline AWM & $\mathbf{4 . 0 4}$ & Highly Effective \\
\hline
\end{tabular}

Understanding own strengths and weaknesses. With an Average Weighted Mean of 3.95, the school administrators were known to be highly effective in understanding their own strengths and weaknesses. This means that the school administrators knew themselves well and they could handle their own developmental needs.

Table 11: Effectiveness of School Administrators in Leadership Skills(Understanding Own Strengths and Weaknesses)

\begin{tabular}{|c|c|c|}
\hline Indicators & WM & Description \\
\hline $\begin{array}{c}\text { The School Administrator recognizes and } \\
\text { appropriately communicates his/her own strengths. }\end{array}$ & 3.9 & Highly Effective \\
\hline $\begin{array}{c}\text { He/she recognizes and manages his/her own } \\
\text { developmental needs. }\end{array}$ & 3.94 & Highly Effective \\
\hline $\begin{array}{c}\text { He/she actively pursues personal growth through } \\
\text { participation in planned developmental activities }\end{array}$ & 4.00 & Highly Effective \\
\hline AWM & $\mathbf{3 . 9 5}$ & Highly Effective \\
\hline Decision Making Skills & 3.93 & Highly Effective \\
\hline Human Relation Skills & 4.09 & Highly Effective \\
\hline Tactful Skills & 4.05 & Highly Effective \\
\hline Directive Skills & 4.11 & Highly Effective \\
\hline Management Skills & 4.04 & Highly Effective \\
\hline Competency Skills & 3.94 & Highly Effective \\
\hline Motivational Skills & 3.99 & Highly Effective \\
\hline Commitment Skills & 4.04 & Highly Effective \\
\hline Observation Skills & 3.93 & Highly Effective \\
\hline Equality Skills & 4.49 & Highly Effective \\
\hline
\end{tabular}

In the same manner, they too were highly effective in decision-making, human relations, tactfulness, direction, management, competency, motivational, commitment, observation and equality skills.

\section{School Administrators' Leadership Behaviors}

This part displays the leadership behaviors of school administrators in various such as framing the school goals, supervision and evaluation of instruction, coordinating the curriculum, monitoring student progress, protecting instructional time, maintaining high visibility, providing incentives for teachers, promoting professional development, and providing incentives for learning. These data are presented in the following tables with corresponding discussions.

Table 12: School Administrators' Leadership Behaviors(Frame the School Goals)

\begin{tabular}{|l|c|c|}
\hline Indicators & WM & Description \\
\hline Develop a focused set of annual school-wide & 4.26 & Highly Effective \\
\hline $\begin{array}{c}\text { Frame the school goals in terms of staff } \\
\text { responsibilities for meeting them. }\end{array}$ & 3.98 & Highly Effective \\
\hline $\begin{array}{c}\text { Use needs assessment or other formal and } \\
\text { informal methods to secure staff input on goal development. }\end{array}$ & 3.94 & Highly Effective \\
\hline $\begin{array}{c}\text { Use data on student performance when } \\
\text { developing the school's academic goals. }\end{array}$ & 4.03 & Highly Effective \\
\hline $\begin{array}{c}\text { Develop goals that are easily understood and used } \\
\text { by teachers in the school. }\end{array}$ & 4.02 & Highly Effective \\
\hline AWM & $\mathbf{4 . 0 5}$ & Highly Effective \\
\hline
\end{tabular}


Frame the school goals. As depicted, the school administrators manifested highly effective behaviors in framing the school goals, generating an Average Weighted Mean of 4.05 dubbed as Highly Effective. This means that the school administrators placed premium in setting academic goals of the schools.

Table 13: School Administrators' Leadership Behaviors(Communicate the School Goals)

\begin{tabular}{|c|c|c|}
\hline $\begin{array}{c}\text { Indicators } \\
\text { Communicate the school mission effectively to } \\
\text { members of the school community. }\end{array}$ & WM & Description \\
\hline $\begin{array}{c}\text { Discuss the school's academic goals with teacher } \\
\text { at faculty meetings }\end{array}$ & 4.10 & Highly Effective \\
\hline $\begin{array}{c}\text { Refer to the school's academic goals when } \\
\text { making curricular decisions with teachers. }\end{array}$ & 4.08 & Highly Effective \\
\hline $\begin{array}{c}\text { Ensure that the school's academic goals are } \\
\text { reflected in highly visible displays in the school (e.g., posters } \\
\text { or bulletin boards emphasizing academic progress) }\end{array}$ & 3.97 & Highly Effective \\
\hline $\begin{array}{c}\text { Refers to the school goals or mission in forums } \\
\text { with students (e.g., in assemblies or discussions) }\end{array}$ & 3.9 & Highly Effective \\
\hline AWM & $\mathbf{4 . 0 1}$ & Highly Effective \\
\hline
\end{tabular}

Communicate the school goals. Obtaining an Average Weighted Mean of 4.01, the school administrators perceived themselves as highly effective in communicating the school goals. This implies that the school administrators directly connect and relate to other members of the academic community in ascertaining the school goals. Likewise, this implies that they make every sector inside the school as well as the community and other stakeholders participate and cooperate in promoting the academic goals.

Table14: School Administrators' Leadership Behaviors(Supervise and Evaluate Instruction)

\begin{tabular}{|c|c|c|}
\hline Indicators & WM & Description \\
\hline $\begin{array}{c}\text { Ensure that the classroom priorities of teachers } \\
\text { are consistent with the goals and direction of the school. }\end{array}$ & 4.05 & Highly Effective \\
\hline $\begin{array}{c}\text { Review student work products when evaluating } \\
\text { classroom instruction. }\end{array}$ & 3.98 & Highly Effective \\
\hline $\begin{array}{c}\text { Conduct informal observations in classrooms on a } \\
\text { regular basis (informal observations are unscheduled, last at } \\
\text { least 5 minutes, and may or may not involve written } \\
\text { feedback or a formal conference) }\end{array}$ & 3.92 & Highly Effective \\
\hline $\begin{array}{l}\text { Point out specific strength's in teacher's } \\
\text { instructional practices in post-observation feedback (e.g., in } \\
\text { conferences or written evaluations). }\end{array}$ & 3.94 & Highly Effective \\
\hline $\begin{array}{l}\text { Point out specific weaknesses in teacher } \\
\text { instructional practices in post-observation feedback (e.g., in } \\
\text { conferences or written evaluations). }\end{array}$ & 3.9 & Highly Effective \\
\hline AWM & $\mathbf{3 . 9 6}$ & Highly Effective \\
\hline
\end{tabular}

Supervise and evaluate instruction. In supervising and evaluating instruction, the school administrators were rated highly effective as indicated in the Average Weighted Mean of 3.96 translated as Highly Effective. The school administrators did their supervisory and evaluative tasks excellently. This means that instructional practices and goals are being well-taken care of and properly monitored to bring out the best in the schools.

Table 15: School Administrators' Leadership Behaviors(Coordinate the Curriculum)

\begin{tabular}{|c|c|c|}
\hline $\begin{array}{c}\text { Indicators } \\
\text { Make clear who is responsible for coordinating } \\
\text { the curriculum across grade levels (e.g., the principal, vice- } \\
\text { principal, or teacher-leaders). }\end{array}$ & WM & Description \\
\hline $\begin{array}{c}\text { Draw upon the results of school-wide testing } \\
\text { when making curricular decisions. }\end{array}$ & 3.94 & Highly Effective \\
\hline $\begin{array}{c}\text { Monitor the classroom curriculum to see that it } \\
\text { covers the school's curricular objectives }\end{array}$ & 3.98 & Highly Effective \\
\hline $\begin{array}{c}\text { Assess the overlap between the school's } \\
\text { curricular objectives and the school's achievement tests. }\end{array}$ & 3.81 & Highly Effective \\
\hline Participate actively in the review of curricular \\
materials.
\end{tabular}

Coordinate the curriculum. The school administrators were observed to be highly effective by garnering an Average Weighted Mean of 3.93 interpreted as Highly Effective. The school administrators take full responsibility in making the curriculum dynamic, responsive, relevant and sustainable. 
Effectiveness of School Administrators' Leadership Skills and Behaviors and their School...

Table 16: School Administrators' Leadership Behaviors(Monitor Student Progress)

\begin{tabular}{|c|c|c|}
\hline Indicators & WM & Description \\
\hline Meet individually with teachers to discuss student & 3.94 & Highly Effective \\
progress. & 3.99 & Highly Effective \\
\hline $\begin{array}{c}\text { Discuss academic performance results with the } \\
\text { faculty to identify curricular strengths and weaknesses. }\end{array}$ & 4.05 & Highly Effective \\
\hline $\begin{array}{c}\text { Use tests and other performance measure to } \\
\text { assess progress toward school goals. }\end{array}$ & 3.99 & Highly Effective \\
\hline $\begin{array}{c}\text { Inform teachers of the school's performance test } \\
\text { results in written form (e.g., in a memo or newsletter). }\end{array}$ & 3.98 & Highly Effective \\
\hline Inform students of school academic progress. & $\mathbf{3 . 9 9}$ & Highly Effective \\
\hline AWM & &
\end{tabular}

Monitor student progress. From the given data, the school administrators attained an Average Weighted Mean of 3.99 interpreted as Highly Effective. Monitoring of students' progress especially in the academics is pursued seriously and thoroughly by the school administrators. This implies that the schools adopt a comprehensive system of monitoring student progress.

Table 17: School Administrators' Leadership Behaviors(Protect Instructional Time)

\begin{tabular}{|c|c|c|}
\hline Indicators & WM & Description \\
\hline $\begin{array}{c}\text { Limit interruptions of instructional time by public } \\
\text { address announcements. }\end{array}$ & 3.84 & Highly Effective \\
\hline $\begin{array}{c}\text { Ensure that students are not called to the office } \\
\text { during instructional time. }\end{array}$ & 3.88 & Highly Effective \\
\hline $\begin{array}{c}\text { Ensure that tardy and truant students suffer } \\
\text { specific consequences for missing instructional time. }\end{array}$ & 3.88 & Highly Effective \\
\hline $\begin{array}{c}\text { Encourage teachers to use instructional time for } \\
\text { teaching and practicing new skills and concepts. }\end{array}$ & 3.91 & Highly Effective \\
\hline $\begin{array}{c}\text { Limit the instruction of extra- and co-curricular } \\
\text { activities. }\end{array}$ & 3.88 & Highly Effective \\
\hline AWM & $\mathbf{3 . 8 8}$ & Highly Effective \\
\hline
\end{tabular}

Protect instructional time. In this criterion the school administrators were also highly effective as projected by an Average Weighted Mean of 3.38 recognized as Highly Effective. It is being implied from the data that time is being utilized wisely and properly for instructional purposes. This goes to show that proper time management is being observed in the schools mainly for academic benefits of the learners.

Table 18: School Administrators’ Leadership Behaviors(Maintain High Visibility)

\begin{tabular}{|c|c|c|}
\hline Indicators & WM & Description \\
\hline $\begin{array}{c}\text { Take time to talk informally with students and } \\
\text { teachers during recess and breaks. }\end{array}$ & 3.94 & Highly Effective \\
\hline $\begin{array}{c}\text { Visit classrooms to discuss school issues with } \\
\text { teachers and students. }\end{array}$ & 3.98 & Highly Effective \\
\hline $\begin{array}{c}\text { Attend and participate in extra- and co-curricular } \\
\text { activities. }\end{array}$ & 4.04 & Highly Effective \\
Cover classes for teachers until a late or substitute \\
teacher arrives. \\
Tutor students or provide direct instruction to \\
classes.
\end{tabular}

Maintain high visibility. Gaining an Average Weighted Mean of 3.95, the school administrators were highly effective in maintaining high visibility. The school administrators exhibit transparency in service and can easily blend with teachers and students. Additionally, they tend to supplement available resources especially in instruction when the need arises. This even implies their modeling desirable leadership behavior worth emulating to the teachers and students.

Table 19: School Administrators' Leadership Behaviors(Provide Incentives for Teachers)

\begin{tabular}{|c|c|c|}
\hline Indicators & WM & Description \\
\hline $\begin{array}{c}\text { Reinforce superior performance by teachers in } \\
\text { staff meetings, newsletters, and/or memos }\end{array}$ & 3.84 & Highly Effective \\
\hline $\begin{array}{c}\text { Compliment teachers privately for their efforts or } \\
\text { performance. }\end{array}$ & 3.88 & Highly Effective \\
\hline $\begin{array}{c}\text { Acknowledge teacher's exceptional performance } \\
\text { by writing memos for their personnel files. }\end{array}$ & 3.87 & Highly Effective \\
\hline $\begin{array}{c}\text { Reward special efforts by teachers with } \\
\text { opportunities for professional recognition. }\end{array}$
\end{tabular}


Effectiveness of School Administrators' Leadership Skills and Behaviors and their School...

\begin{tabular}{|c|c|c|}
\hline $\begin{array}{c}\text { Create professional growth opportunities for } \\
\text { teachers as a reward for special contributions to the school. }\end{array}$ & 3.80 & Highly Effective \\
\hline AWM & $\mathbf{3 . 8 6}$ & Highly Effective \\
\hline
\end{tabular}

Provide incentives for teachers. In providing incentives for teachers, the school administrators obtained an Average Weighted Mean of 3.86 which means Highly Effective. The school administrators consider and value the role of the teachers as their partners in accomplishing the schools' academic goals. This would mean greater motivation for the teachers to perform their jobs better and to ensure improved academic performance.

Table 20: School Administrators' Leadership Behaviors(Promote Professional Development)

\begin{tabular}{|c|c|c|}
\hline Indicators & WM & Description \\
\hline $\begin{array}{c}\text { Ensure that in-service activities attended by staff } \\
\text { are consistent with the school's goals. }\end{array}$ & 4.0 & Highly Effective \\
\hline $\begin{array}{c}\text { Actively support the use in the classroom of skills } \\
\text { acquired during in-service activities. }\end{array}$ & 4.0 & Highly Effective \\
\hline $\begin{array}{c}\text { Obtain the participation of the whole staff in } \\
\text { important in-service training. }\end{array}$ & 4.11 & Highly Effective \\
\hline $\begin{array}{c}\text { Lead or attend teacher in-service activities } \\
\text { concerned with instruction. }\end{array}$ & 4.1 & Highly Effective \\
\hline $\begin{array}{c}\text { Set aside time at faculty meetings for teachers to } \\
\text { share ideas or information from in-service activities. }\end{array}$ & 4.11 & Highly Effective \\
\hline AWM & $\mathbf{4 . 0 6}$ & Highly Effective \\
\hline
\end{tabular}

Promote professional development. As elicited from the table, the school administrators were highly effective as regard their behavior in promoting professional development. It can be inferred that professional development of teachers is the major concern of the school administrators and they make sure that the teachers' in-service trainings are well attended. This implies also that a good rapport between the school administrators and teachers is manifested.

Table 21: School Administrators' Leadership Behaviors(Provide Incentives for Learning)

\begin{tabular}{|c|c|c|}
\hline Indicators & WM & Description \\
\hline $\begin{array}{c}\text { Recognize students who do superior work with } \\
\text { formal rewards such as an honor roll or mention in the } \\
\text { principal's newsletter. }\end{array}$ & 3.94 & Highly Effective \\
\hline $\begin{array}{c}\text { Use assemblies to honor students for academic } \\
\text { accomplishments or for behavior or for citizenship. }\end{array}$ & 3.95 & Highly Effective \\
\hline $\begin{array}{c}\text { Use assemblies to honor students for academic } \\
\text { accomplishments or for behavior or for citizenship. }\end{array}$ & 3.98 & Highly Effective \\
\hline $\begin{array}{c}\text { Contact parents to communicate improved or } \\
\text { exemplary student performance or contributions. }\end{array}$ & 4.06 & Highly Effective \\
\hline $\begin{array}{c}\text { Support teachers actively in their recognition } \\
\text { and/or and } \\
\text { reward student contributions to and }\end{array}$ & 4.18 & Highly Effective \\
\hline AWM & & Highly Effective \\
\hline
\end{tabular}

Provide incentives for learning. The school administrators were found to be highly effective in providing incentive for learning as seen through an Average Weighted Mean of 4.02 which means Highly Effective. It is noticeable that the school administrators provide huge support to students especially those who excel academically. As an implication, students will become highly motivated as well as inspired to do better in their studies and to learn more as their efforts are to be recognized by the school heads.

\section{School Performance of Area III Leyte Division}

The School Performance of Area III in Leyte Division covers only the School Years 2011-2012 and 2012-2013. No data were secured for School Year 2013-2014 since records were destroyed by typhoon Yolanda. Presentation and discussion of the data is shown in Table 22.

Table 22: School Performance in Area III Leyte Division

\begin{tabular}{|l|l|l|l|l|}
\hline \multirow{2}{*}{ Rating } & SY 2011-2012 & \multicolumn{2}{l|}{ SY 2012-2013 } \\
\cline { 2 - 5 } & f & \% & f & \% \\
\hline 96-100 (Mastered) & 0 & 0 & 0 & 0 \\
\hline 86-95 (Closely Approximating Mastery) & 19 & 17.3 & 33 & 30.0 \\
\hline 66-85 (Moving Towards Mastery) & 87 & 79.1 & 70 & 63.6 \\
\hline 35-65 (Average) & 4 & 3.6 & 7 & 6.4 \\
\hline 15-34 (Low) & 0 & 0 & 0 & 0 \\
\hline 5-14 (Very Low) & 0 & 0 & 0 & 0 \\
\hline
\end{tabular}


Effectiveness of School Administrators' Leadership Skills and Behaviors and their School...

\begin{tabular}{|c|l|l|l|l|}
\hline $0-4$ (Absolutely No Mastery) & 0 & 0 & 0 & 0 \\
\hline Total & $\mathbf{1 1 0}$ & $\mathbf{1 0 0 . 0 0}$ & $\mathbf{1 1 0}$ & $\mathbf{1 0 0 . 0 0}$ \\
\hline
\end{tabular}

As gleaned from the table, majority of the schools in the School Year 2011-2012 achieved Moving Towards Mastery, which is followed by Closely Approximating Mastery. Only few, which is the remaining group, were in the Average level. However, none reached Mastered level. From these findings, it can be noted that the school recipients performed academically well since none fell in the Low, Very Low and Absolutely No Mastery levels. Yet, the results would also imply that efforts to raise the school performance can still be increased until a point when Mastered level is reached.

It appears that in the School Year 2012-2013 the number of those who reached Closely Approximating Mastery nearly doubled and those in the Average level slightly raised. None, however, fell into Low, Very Low and Absolutely No Mastery levels. But the findings show that the schools may still strive to sustain or even surpass its targets and plans for academic goals since no one had attained Mastered level. As elucidated in the School Performances for the two School Years, the performance has increased since in the current School Year the number of schools reaching Closely Approximating Mastery nearly doubled. It would be interesting to see the trend of the succeeding School Years to establish a strong database as to how the performance had been going. Thus, it can be ascertained as to whether it is decreasing or increasing.

\section{Relationship of Variables}

The relationship of variables is another objective measured in the study. This was ascertained to determine whether there are or no relationships existed among these variables. This is presented in the succeeding tables.

The data on table 23 presents the relationship between the profile of the school administrators and their leadership skills. For the profile variables on sex, civil status, official designation, age, highest educational attainment and seminars and training attended, only the variable on seminars and training attended particularly in international level shows significant relationship as correlated to leadership skills.

Table 23: Relationship between the Profile of School Administrators and their Leadership Skills

\begin{tabular}{|l|l|l|l|l|}
\hline Variable & $\mathbf{X}^{2}$ & df & Asymp. Sig. & Decision \\
\hline Sex & 13.553 & 13 & .406 & Ho Accepted \\
\hline Civil Status & 36.462 & 39 & .586 & Ho Accepted \\
\hline Official Designation & 38.606 & 52 & .916 & Ho Accepted \\
\hline Variable & r-value & & Sig.(2-tailed) & Decision \\
\hline Age & .184 & & .438 & Ho Accepted \\
\hline Highest Educational Attainment & .262 & & .264 & Ho Accepted \\
\hline Training Local & -.103 & & .666 & Ho Accepted \\
\hline Regional & -.037 & & .876 & Ho Accepted \\
\hline National & .040 & & .868 & Ho Accepted \\
\hline International & $-.484^{*}$ & & .031 & Ho Rejected \\
\hline Length of Administrative Experience & .168 & & .478 & Ho Accepted \\
\hline
\end{tabular}

*Correlation is significant at the 0.05 level

The computed value (-.484) is lesser than asymp. Sig. of .031 with the df at alpha $=.005$. The hypothesis that there is no significant relationship between the seminars and trainings attended by the school administrators and their leadership skills was rejected and therefore significant. Implication can be drawn that the school administrators' seminars and trainings attended is directly related or affected by their leadership skills. This means that there is an urgent need to expose them to international seminars and trainings to gain more insights and make them more skilled in leading their posts.

Table 24: Relationship between the Profile of the School Administrators and their Leadership Behaviour

\begin{tabular}{|l|l|l|l|l|}
\hline Variable & $\mathbf{X}^{\mathbf{2}}$ & $\mathbf{d f}$ & Asymp. Sig. & Decision \\
\hline Sex & 10.00 & 9 & .350 & Ho Accepted \\
\hline Civil Status & 20.00 & 18 & .333 & Ho Accepted \\
\hline Official Designation & 30.00 & 27 & .314 & Ho Accepted \\
\hline Variable & r-value & \multicolumn{2}{|l|}{ Sig.(2-tailed) } & Decision \\
\hline Age & -.013 & & .972 & Ho Accepted \\
\hline Highest Educational Attainment & .014 & & .969 & Ho Accepted \\
\hline Training Local & .075 & & .836 & Ho Accepted \\
\hline Regional & -.200 & & .580 & Ho Accepted \\
\hline National & -.031 & & .932 & Ho Accepted \\
\hline International & .213 & & .555 & Ho Accepted \\
\hline Length of Administrative Experience & -.420 & & .227 & Ho Accepted \\
\hline
\end{tabular}

*Correlation is significant at the 0.05 level 
Displayed in the table is the data on the relationship between the profile of the school administrators and their leadership behavior. For the profile variables on gender, civil status, highest educational attainment, age and number of years as correlated to management behavior, the computed values of these variables were greater than the r-values. The hypothesis that there is no significant relationship between the profile and management behavior of the school heads was accepted and therefore not significant. The results imply that the profile does not relate or affect the management behavior of the school heads

Table 25: Relationship between the Profile of the School Administrators and the School Performance

\begin{tabular}{|c|c|c|c|c|}
\hline Variable & $\mathbf{X}^{2}$ & df & Asymp. Sig. & Decision \\
\hline Sex & 101.667 & 98 & .380 & Ho Accepted \\
\hline Civil Status & 434.53 & 392 & .068 & Ho Accepted \\
\hline Official Designation & 504.541 & 490 & .315 & Ho Accepted \\
\hline Variable & r-value & & Sig.(2-tailed) & Decision \\
\hline Age & .073 & & .450 & Ho Accepted \\
\hline Highest Educational Attainment & -.092 & & .338 & Ho Accepted \\
\hline Training Local & -.076 & & .428 & Ho Accepted \\
\hline Regional & -.058 & & .544 & Ho Accepted \\
\hline National & -.052 & & .593 & Ho Accepted \\
\hline International & -.052 & & .606 & Ho Accepted \\
\hline Length of Administrative Experience & .121 & & 208 & Ho Accepted \\
\hline
\end{tabular}

*Correlation is significant at the 0.05 level

The table provides data on the relationship between the profile of school administrators and the school performance. For the variables on sex, civil status and official designation, the r-values are greater than the Asymp. Sig. with their corresponding $\mathrm{df}$ at alpha $=0.05$. This means that the hypothesis that there is no significant relationship between selected variables on the profile of the school administrators and their school performance was accepted and therefore no significance. Data claims that sex, civil status and official designation of school administrators do not affect or are not related to their school performance.

In the meantime, profile variables on age, highest educational attainment, seminars/trainings and length of administrative experience garnered r-values lower than Asym. Sig. with corresponding df at alpha=0.05 which means that the hypothesis which says that there is no significant relationship between the profile of the school administrators and their school performance was rejected and therefore significant. Implication suggests that the age, educational attainment, seminars/trainings and length of administrative experience of school administrators have effect or are related to their school performance.

Table 26: Relationship between the School Administrators' Leadership Skills and their Leadership Behaviour

\begin{tabular}{|l|l|l|l|}
\hline Variable & r-value & Sig.(2-tailed) & Decision \\
\hline Leadership Skills and Behaviour & .427 & .218 & Ho Accepted \\
\hline
\end{tabular}

*Correlation is significant at the 0.05 level

Table 26 presents data on relationship between the school administrators' leadership skills and their leadership behavior. The r-value (.427) is greater than the Sig. (2-tailed) (.218) at alpha $=0.05$ which means that the hypothesis that says there is no significant relationship between the school administrators' leadership skills and their leadership behavior was accepted which means not significant. This only advances an implication that the school administrators' leadership skills do not affect or is not related to their leadership behavior.

Table 27: Relationship between the Profile of the School Administrators' Leadership Skills and School Performance

\begin{tabular}{|l|l|l|l|}
\hline Variable & r-value & Sig.(2-tailed) & Decision \\
\hline Leadership Skills and School Performance & -1.09 & .647 & Ho Accepted \\
\hline
\end{tabular}

*Correlation is significant at the 0.05 level

As gleaned from the table, the data highlights the relationship between the school administrators' leadership skills and their school performance. The r-value (-1.09) is lesser than the Sig. (2-tailed) (.647) at alpha $=0.05$ which means that the hypothesis that says there is no significant relationship between the school administrators' leadership skills and their school performance was rejected which means significant. Results pave the way to an implication that the school administrators' leadership skills are indeed related or could strongly affect the school performance.

Table 28: Relationship between the School Administrators'Leadership Behavior and School Performance

\begin{tabular}{|l|l|l|l|}
\hline Variable & r-value & Sig.(2-tailed) & Decision \\
\hline Leadership Bahaviour and School Performance & -.234 & .516 & Ho Accepted \\
* Correlation is significant at the 0.05 level
\end{tabular}


Table 28 contains data on the relationship between the school administrators' leadership behavior and their school performance. Evidently, the r-value (-.234) is lesser than the Sig. (2-tailed) (.516) at alpha =0.05 which means that the hypothesis that says there is no significant relationship between the school administrators' leadership behavior and their school performance was rejected which means significant. From the given data, implications mean that the school administrators' leadership behavior could affect or is strongly related to school performance.

\section{Conclusion}

The school administrators exhibited the need for improvement as evidenced by its lack of higher exposure particularly on seminars and trainings attended in the international level. Insofar as leadership skills are concerned, the school administrators have also proven their effectiveness on such function. Similarly, they too possessed effectiveness in terms of their leadership behavior. Thus, school performance appeared to have strong correlations to selected socio-demographic profile variables and leadership skills of the school administrators.

\section{Recommendation}

Based on the findings and conclusions of the study, the following recommendations are hereby offered for consideration.1.)Although most of the school administrators are academically qualified, they may still continue pursue higher studies like doctorate in order to equip them with advanced and more adequate knowledge, skill and competence to be able to perform their respective tasks inherent to their positions. 2.)The Department of Education particularly in Area III Leyte Division may consider providing opportunities for the school heads to be sent to seminars and trainings in the national and international levels in which they were found to be deficient.3.)Some factors like age, educational attainment, seminars/trainings attended and length of work experience should be incorporated as determinants and key measures in the designation and appointment of a school administrator if only to put somebody who truly exemplifies competence and excellence in service.4.)Parallel studies maybe conducted by examining other aspects and nature of variables related to leadership skills and behaviour so that further assessments on the reliability and validity of the data in this research could be ascertained.

\section{References}

[1] Baltazar, Jose D. et. al. (2004). Management in the Philippine setting, National Book Store

[2] Blasé, J. (2001). Empowering teachers: What successful principals do (2 $2^{\text {nd }}$ Ed). Thousand Oaks, CA: Corwin Press.

[3] Cotton, K. (2003). Principals and student achievement: What research says.Alexandre VA Associates for Supervision and Curriculum Development.

[4] Darling, Hammond (2004). Standards accountability and school reform.Teacher college record.

[5] Elmor, Ruchard (2004). School reform from the inside out: Policy practice and performance. Cambridge MA:Harvard Education Premier

[6] Magda, Rod M. (2003). The appropriate leadership styles and techniques in the $21^{\text {st }}$ century. The Modern Teacher.

[7] Manzanero, Belen R. (2003). What it takes to be principal. The Modern Teacher.

[8] Mc Evan, E. (2002). Seven steps to effective instructional leadership. California Crown Press, Inc.

[9] Sergiovanni, T. (2000). Leadership for school house. San Francisco, Jossey-Bann

[10] Tan, Elsie A. (2014). Instructional leadership of principals in the Division of Biliran; Unpublished Masters Thesis: Naval State University.

[11] Zapeda, S. (2003). Instructional supervision: Applying tools and concepts. New York. Eye on Education.

[12] Angeles, Eduardo P. (2010). Leadership - Key Element in Organizational Management.The Modern Teacher Vol. 59.

[13] Gosling, Bolden R and Manterano, J. and Denisson, P. (2003). A Review of Leadership Theory and Competency Frameworks.

[14] Martires, C.R and Fule G.S (2000). Management of Human Behavior, Second Edition.

[15] Leila G. Viduya (2000). Leadership.The Modern Teacher Vol. 50.

[16] Aquino, Jonathan (2007). Leadership in the Philippines Panorama.

[17] Desamito, Rosabel (2010). What it takes to be a Leader. The Modern Teacher Vol. 50.

[18] Dela Cruz, John (2010). Five Salient Points to be considered by Leaders in Making Decisions. The Modern Teacher Vol. 50.

[19] Blasé, J., \& Blasé, J. (2000). Effective instructional leadership: Teachers' perspectives on how principals promote teaching and learning in schools. Journal of Educational Administration, 38, 130-141.

[20] Day,C. (2000). Beyond transformational leadership.Educational Leadership, 57(7), 56- 59.

[21] DuFour, R., \&Berkey, T. (1995). The principal as staff developer. Journal of Staff Development, 16(4), 2-6.

[22] Heck, R. H., Larsen, T. J., \&Marcoulides, G. A., (1990). Instructional leadership and school achievement: Validation of a causal model. Educational Administration Quarterly, 26(2), 94-125.

[23] Hoy, W. K., \&Hannum, J. W. (1997). Middle school climate: An empirical assessment of organizational health and student achievement. Educational Administration Quarterly, 33(3), 290-311.

[24] Leitner, D. (1994). Do principals affect student outcomes: An organizational perspective. School Effectiveness and School Improvement, 5 , 219-238.

[25] Leithwood, K., \&Jantzi, D. (2000). The effects of transformation leadership on student engagement with school. Journal of Educational Administration, 38, 112-129.

[26] Nettles, S. M., \& Herrington, C. (2007). Revisiting the importance of the direct effects of school leadership on student achievement: The implications for school improvement policy. Peabody Journal of Education, 82 (4), 724-736. 
[27] Marzano, R. J., Waters, T., \& McNulty, B. A. (2005). School leadership that works . Alexandria, VA: Association for Supervision and Curriculum Development.

[28] Pepper, K., \& Thomas, L. H. (2002). Making a change: The effects of the leadership role on schools climate. Learning Environments Research, 5 , 155-166.

[29] Rea, P.J., McLaughlin, V. L., \& Walther-Thomas, C.J. (2002). A comparison of outcomes for middle school students with learning disabilities in inclusive and pullout programs. Exceptional Children, 68, 203-222.

[30] Saphier, J., King, M., \&D’Auria, J. (2006). 3 Strands form strong school leadership. Journal of Staff Development, 27 (2), 51 -59. 